\title{
Characterization of Iprodione Resistance in Botrytis cinerea from Strawberry and Blackberry
}

\author{
Anja Grabke, Dolores Fernández-Ortuño, Achour Amiri, Xingpeng Li, \\ Natália A. Peres, Powell Smith, and Guido Schnabel
}

First, second, fourth, and seventh authors: School of Agricultural, Forest \& Environmental Sciences, Clemson University, Clemson, SC 29634; second author: Instituto de Hortofruticultura Subtropical y Mediterránea "La Mayora"-Universidad de Málaga-Consejo Superior de Investigaciones Científica (IHSM-UMA-CSIC), Campus de Teatinos, 29071 Málaga, Spain; third and fifth authors: Gulf Coast Research and Education Center, University of Florida, Wimauma 33598; and sixth author: Clemson University Extension Service, Lexington, SC 29072.

Accepted for publication 18 October 2014.

\begin{abstract}
Grabke, A., Fernández-Ortuño, D., Amiri, A., Li, X., Peres, N. A., Smith, P., and Schnabel, G. 2014. Characterization of iprodione resistance in Botrytis cinerea from strawberry and blackberry. Phytopathology 104:396-402.

Gray mold, caused by the fungal pathogen Botrytis cinerea, is one of the most destructive diseases of strawberry. Control of the disease in commercial fields is largely dependent on the application of fungicides, including the dicarboximide iprodione. Single-spore isolates were collected from strawberry fields in Florida, North Carolina, and South Carolina and subjected to an assay using conidial germination that distinguished sensitive (S) isolates from isolates with various levels of resistance to iprodione. Of the 245 isolates, 1 was highly resistant (HR), 5 were moderately resistant (MR), and 43 had low resistance (LR) to iprodione. LR and MR strains were found in the Florida population and in 9 of 11 locations from North Carolina and South Carolina, indicating that resistance was widespread but accounted for only a relatively small percentage of

codes for a class III histidine kinase, revealed that the MR phenotype was associated with Q369P and N373S mutations and that the LR phenotype was associated with either a I365S or a I365N mutation. The I365S and I $365 \mathrm{~N}$ mutations were also present in five additionally included HR isolates from North Carolina and South Carolina blackberry fields and one HR isolate from a Virginia strawberry field but no mutation or mutation combinations in bos 1 were uniquely associated with the HR phenotype. Expression analysis of bosl in S and HR isolates did not reveal convincing evidence of the gene's involvement in HR resistance either. The six HR isolates had three different phenotypes with respect to their sensitivity to fludioxonil; two were $\mathrm{S}$, two were LR, and two were MR. The fludioxonil LR and MR isolates were also resistant to tolnaftate, an indication of multidrug efflux pump activity. These data suggest that, in addition to point mutations in bos 1 , drug efflux pump activity and potentially a third mechanism of resistance may be contributing to the iprodione HR phenotype. Detached fruit studies showed that field rates of Rovral 4 Flowable (iprodione) did not control iprodione MR and HR isolates.
\end{abstract} the $B$. cinerea population. Sequence analysis of the target gene bos 1 , which
Gray mold, also known as Botrytis fruit rot, is one of the most destructive diseases of cultivated strawberry (Fragaria $\times$ ananassa) in the United States and in other production areas worldwide. Flowers are infected first, mostly from conidia germinating on petals, stamens, and pistils, and infections remain latent until weather conditions become favorable and symptoms are eventually expressed on green and ripe fruit. Secondary infections occur through contact of healthy fruit with infected plant material or via conidia that are spread from symptomatic to healthy fruit via wind and rain splash (49). In the southeastern United States, the disease is mainly caused by the plant-pathogenic fungus Botrytis cinerea Pers. but fruit can also be affected by B. caroliniana X. P. Li \& Schnabel $(17,18,30,31)$. Preharvest crop loss resulting from infections by $B$. cinerea is especially severe under moist conditions and temperatures of around $20^{\circ} \mathrm{C}$.

Chemical control during bloom and fruit maturation remains the main approach to control gray mold in commercial strawberry fields. In addition to the multisite fungicides captan and thiram, site-specific fungicides of seven different chemical classes are currently available for gray mold management in the southeastern United States, including anilinopyrimidines (APs), dicarboxi-

Corresponding author: G. Schnabel; E-mail address: schnabe@clemson.edu

http://dx.doi.org/10.1094/PHYTO-06-13-0156-R

(c) 2014 The American Phytopathological Society mides (DCs), hydroxyanilides (HAs), methyl benzimidazole carbamates (MBCs), quinone outside inhibitors (QoIs), phenylpyrroles (PPs), and succinate dehydrogenase inhibitors (SDHIs). Many of the site-specific fungicides are considered reducedhealth-risk fungicides due to their generally higher efficacy, lower toxicity, and lower application rates but these advantages are somewhat offset by their vulnerability to resistance development. Botrytis cinerea is known for its ability to develop resistance quickly (29) and, in fact, resistance in $B$. cinerea from strawberry fields in the southeastern United States has been reported to AP, HA, MBC, SDHI, and QoI fungicides $(1,15,16,19,21)$.

The DC iprodione is a site-specific fungicide which has, compared with many other classes of fungicides, a relatively narrow spectrum of activity that includes Botrytis spp. and the closely related genera Monilinia and Sclerotinia (10,50). The fungicide has been used to control B. cinerea since the late 1970s and resistance has emerged on different crops in many areas where DCs had been used frequently $(25,28,29,33,43)$. For example, iprodione-resistant $B$. cinerea isolates from strawberry were found in Australia (44), Germany (45), Israel (12), New Zealand (3), and Spain (11). Reports of resistance from the southeastern and eastern United States are rare. Resistance to DCs was reported in $B$. cinerea isolates from three strawberry nurseries in North Carolina, several strawberry farms in Louisiana and Oregon, and greenhouse-grown ornamental crops in South Carolina $(4,15,24,47,48,51)$; however, no comprehensive study of the occur- 
rence and prevalence of iprodione resistance or mechanisms of resistance has been conducted for isolates from strawberry fields of the Eastern United States.

Isolates of $B$. cinerea resistant to iprodione may possess low, moderate, or high levels of resistance. Low to moderate levels are typically found in field isolates, whereas high levels of resistance have been found in laboratory mutants and are rarely seen in field isolates. Cross resistance between isolates resistant to PPs and DCs was observed in laboratory mutants but has rarely been found under field conditions $(13,28,45)$. Genetic analysis of DCresistant $B$. cinerea isolates revealed that resistance was usually linked to a single gene, bosl (also called BcOS1 or Daf1), but a second gene (daf2) was involved in conferring resistance in laboratory mutants (13). Bosl codes for a class III histidine kinase which is involved in the adaptation to adverse environmental conditions such as osmotic and oxidative stress. This osmosensing histidine kinase is also important for the macroconidation and pathogenesis of $B$. cinerea, which may explain the low frequency of highly resistant field strains $(32,34,41)$.

The objectives of this study were to (i) determine the occurrence and frequency of iprodione resistance in $B$. cinerea isolates from commercial strawberry fields in Florida, North Carolina, and South Carolina; (ii) identify mutations in the bosl gene corresponding with the resistance phenotypes; and (iii) examine fitness and pathogenicity of isolates with low, moderate, and high levels of resistance to iprodione.

\section{MATERIALS AND METHODS}

Fungal isolates and culture conditions. In total, 245 singlespore isolates of $B$. cinerea were collected from strawberry fruit with gray mold symptoms: 30 from Florida, 90 from North Carolina, 124 from South Carolina, and 1 (isolate Wland1) from Virginia (Table 1). Most isolates from strawberry fields HP, MV, NC, and SBY in North Carolina and FLOR, GIK, JEY, KUD, MER, MOD, and WIC in South Carolina were used in previous studies to assess the sensitivities and molecular bases of resistance to QoIs, SDHIs, APs, PPs, and HAs $(15,16,21)$. Singlespore isolation was performed as previously described $(16,18)$.

For more thorough investigation of the molecular mechanism of iprodione resistance, isolates from blackberry were included: five with high resistance $(\mathrm{CBa} 82, \mathrm{COa} 3, \mathrm{CO} 20, \mathrm{KC} 25$, and $\mathrm{KC} 33$ ), one with low resistance (MC14), and two sensitive (CA25 and $\mathrm{CBa} 3$ ) to iprodione. The origin of these isolates was reported previously (30). Each isolate had been stored as dried mycelium on filter paper (Whatman Inc., Maidstone, UK) at $-20^{\circ} \mathrm{C}$, as previously described (52), before it was grown on potato dextrose agar (PDA) for experimental use.

Sensitivity of $B$. cinerea isolates to iprodione, fludioxonil, and tolnaftate. The sensitivity of the $B$. cinerea isolates to fludioxonil and iprodione was assessed using a conidial germination assay that distinguishes sensitive isolates from isolates with various levels of resistance (46). Discriminatory concentrations of iprodione at 5 and $50 \mathrm{mg} /$ liter formulated as Rovral 4 Flowable (Bayer CropScience, Durham, NC) permitted a distinction between highly sensitive (SS), sensitive (S), moderately resistant (MR), and highly resistant (HR) isolates. Germ tubes of conidia of SS isolates were completely inhibited at 5 and $50 \mathrm{mg} / \mathrm{liter}$, germ tubes of $\mathrm{S}$ isolates showed residual growth (10 to $25 \%$ of the rate of the control) at $5 \mathrm{mg} /$ liter but were completely inhibited at $50 \mathrm{mg} / \mathrm{liter}$, germ tubes of MR isolates grew 50 to $80 \%$ at $5 \mathrm{mg} / \mathrm{liter}$ and 10 to $40 \%$ at $50 \mathrm{mg} / \mathrm{liter}$, and isolates with a fully developed germ tube at $5 \mathrm{mg} / \mathrm{liter}$ and a germ tube $>50 \%$ at $50 \mathrm{mg} /$ liter were categorized as HR. A new resistance category named low resistant (LR) was assigned to isolates with germ tubes displaying growth of $>80 \%$ at $5 \mathrm{mg} /$ liter but completely inhibited at $50 \mathrm{mg} /$ liter.

Discriminatory doses of fludioxonil at 0.1 and $10 \mathrm{mg} /$ liter were used to distinguish SS, S, MR, and resistant (R) isolates. Germination of conidia of SS isolates was completely inhibited at both concentrations, germ tubes of $\mathrm{S}$ isolates grew 30 to $50 \%$ at $0.1 \mathrm{mg} / \mathrm{liter}$ but were inhibited at $10 \mathrm{mg} / \mathrm{liter}$, germ tubes of MR

TABLE 1. Origin and sensitivity to iprodione of Botrytis cinerea isolates collected from strawberry fields in Florida, North Carolina, South Carolina, and Virginia

\begin{tabular}{|c|c|c|c|}
\hline Iprodione sensitivity, isolates ${ }^{\mathrm{w}}$ & $N^{\mathrm{x}}$ & State $^{y}$ & Year $^{\mathrm{Z}}$ \\
\hline \multicolumn{4}{|l|}{$\overline{\text { SS }}$} \\
\hline $01-37$ & 1 & FL & 2001 \\
\hline $12-19,12-87,12-178$ & 3 & FL & 2012 \\
\hline $\begin{array}{l}\text { FLOR1 to 5, FLOR7 to 13, GIK2, GIK4, GIK6, GIK7, GIK13, GIK15, JEY8, JEY21, KUD1, KUD3, KUD5, KUD13, KUD16, } \\
\text { KUD17, KUD20, MER2, MER3, MOD3, MOD9, MOD10, MOD18, WIC2, WIC4 to 6, WIC8, WIC10 to 13, WIC16 to } 21\end{array}$ & 48 & $\mathrm{SC}$ & 2011 \\
\hline \multicolumn{4}{|l|}{ S } \\
\hline $05-26$ & 1 & FL & 2005 \\
\hline $\begin{array}{l}\text { MV2 to 4, MV7, MV11, NC1 to 10, NC12, SBY2, SBY11, SBY12, SBY17, SBY19 to 22, SBY24, SBY27, SBY29, SBY31, } \\
\text { SBY34 to } 37\end{array}$ & 32 & $\mathrm{NC}$ & 2011 \\
\hline $\begin{array}{l}\text { GIK1, GIK5, GIK8 to 12, GIK14, GIK16, GIK17, GIK19, GIK20, JEY2, JEY5, JEY7, JEY9 to 16, JEY18 to 20, JEY22, KUD2, } \\
\text { KUD4, KUD6 to 12, KUD14, KUD15, KUD18, KUD21, MER1, MOD1, MOD2, MOD11, MOD12, WIC3, WIC9 }\end{array}$ & 47 & SC & 2011 \\
\hline \multicolumn{4}{|l|}{ LR } \\
\hline $10-43$ & 1 & FL & 2010 \\
\hline $12-104$ & 1 & FL & 2012 \\
\hline SBY9, SBY23 & 2 & $\mathrm{NC}$ & 2011 \\
\hline JEY4, JEY6 & 2 & $\mathrm{SC}$ & 2011 \\
\hline \multicolumn{4}{|l|}{ HR } \\
\hline Wland1 & 1 & VA & 2012 \\
\hline
\end{tabular}

${ }^{\text {w }} \mathrm{SS}=$ highly sensitive; $\mathrm{S}=$ sensitive, $\mathrm{LR}=$ low-resistant, $\mathrm{MR}=$ moderately resistant, and $\mathrm{HR}=$ highly resistant. Isolate sensitivity was assessed with a germination assay using iprodione at 5 and $50 \mathrm{mg} / \mathrm{liter}(46)$.

${ }^{x}$ Number of isolates.

${ }^{y} \mathrm{FL}=$ Florida, $\mathrm{NC}=$ North Carolina, $\mathrm{SC}=$ South Carolina, and VA = Virginia.

z Year of isolation. 
isolates grew $>80 \%$ at $0.1 \mathrm{mg} / \mathrm{liter}$ and 10 to $20 \%$ at $10 \mathrm{mg} / \mathrm{liter}$, and germ tubes of $\mathrm{R}$ isolates grew without inhibition at 0.1 $\mathrm{mg} / \mathrm{liter}$ and $>25 \%$ at $10 \mathrm{mg} / \mathrm{liter}$.

Effective inhibitory concentrations $\left(\mathrm{EC}_{50} \mathrm{~s} \quad[\mathrm{mg} / \mathrm{liter}]\right)$ for tolnaftate were assessed as previously described by Kretschmer et al. (26) using 1,000 spores in 0.1-ml 96-microplate cultures and a threefold drug dilution series. Tests were performed in malt extract broth with final concentrations of tolnaftate at 30, 10, 3, 1, $0.3,0.1$, and $0.03 \mathrm{mg} / \mathrm{liter}$. After $48 \mathrm{~h}$ of incubation in the dark at $22^{\circ} \mathrm{C}$, light absorption at an absorbance of $600 \mathrm{~nm}$ was determined. Isolates with $\mathrm{EC}_{50}$ values $<2.5 \mathrm{mg} / \mathrm{liter}$ were designated $\mathrm{S}$ and isolates with $\mathrm{EC}_{50}$ values $>10 \mathrm{mg} /$ liter were designated $\mathrm{R}$.

Analysis of bos 1 gene sequences from isolates with different iprodione resistance phenotypes. To investigate molecular mechanisms of resistance, nucleotide sequences of the bos 1 gene from $S$ and $\mathrm{R}$ isolates were compared. Genomic DNA was extracted from actively growing mycelia using either the MasterPure Yeast DNA Purification Kit (Epicentre, Madison, WI) or a method published previously by $\mathrm{Chi}$ et al. (5). Five primer pairs (BF1/BR1, $\mathrm{BF} 2 / \mathrm{BR} 2, \mathrm{BF} 3 / \mathrm{BR} 3, \mathrm{BF} 4 / \mathrm{BR} 4$, and BF5/BR5) previously published by Ma et al. (34) were used to amplify the complete bos 1 gene from $B$. cinerea isolates listed in Table 2 . In addition, a fragment containing previously described key point mutations in bos 1, including I365N/S/R, Q369H/P, and N373S (2,7,29,34,36, 37) that correlate with resistance to iprodione, was amplified from LR isolates 10-43, JEY2, JEY25, KUD19, MOD4, SBY1, SBY4, SBY7, and SBY10 with primer pair BF2/BR2. Polymerase chain reaction (PCR) reactions were performed in a $25 \mu \mathrm{l}$ volume containing $25 \mathrm{ng}$ of fungal genomic DNA, $5 \mathrm{mM}$ each dNTP, $10 \mathrm{pmol}$ of each primer, $2.5 \mu \mathrm{l}$ of $10 \times$ Thermo Pol Buffer, and $0.625 \mathrm{U}$ of Taq DNA Polymerase (New England Biolabs, Ipswich, MA). PCR was carried out with an iCycler Thermal Cycler (BioRad Laboratories Inc., Hercules, CA) programmed as follows: $3 \mathrm{~min}$ at $95^{\circ} \mathrm{C}$; followed by 40 cycles of $95^{\circ} \mathrm{C}$ for $1 \mathrm{~min}, 60^{\circ} \mathrm{C}$ for $1 \mathrm{~min}$, and $72^{\circ} \mathrm{C}$ for $1.5 \mathrm{~min}$; with a final extension at $72^{\circ} \mathrm{C}$ for 5 min. All amplified PCR products were purified using the
ExoSAP-IT purification kit (USB Corporation, Cleveland) and sequenced at the Clemson University Genomics Institute (Clemson, SC).

RNA extraction and expression analyses. For analysis of bos 1 expression in B. cinerea, $2 \mathrm{ml}$ of potato dextrose broth in polystyrene petri dishes (60 by $15 \mathrm{~mm}$ ) were inoculated with $5 \times$ $10^{6}$ conidia and incubated for $14.5 \mathrm{~h}$ at room temperature on a rotary shaker at $150 \mathrm{rpm}$. The germlings were then incubated for another $30 \mathrm{~min}$ either with or without iprodione $10 \mathrm{ml} / \mathrm{liter}$, formulated as Rovral 4 Flowable (41.6\% [wt/vol] active ingredient; Bayer CropScience). For RNA isolation, the liquid culture was transferred into a 2-ml tube and centrifuged for $4 \mathrm{~min}$ at $10,000 \mathrm{rpm}$. The pellet was washed twice with ice-cold water followed by centrifugation. Total fungal RNA was extracted using the MasterPure Yeast RNA Purification Kit (Epicentre) according to the manufacturer's instructions. RNA concentration and purity were determined using agarose gel electrophoresis and spectrophotometric analysis with a NanoDrop 2000 Spectrophotometer (Thermo Scientific, Waltham, MA). RNA (1 $\mu \mathrm{g})$ was reversetranscribed into cDNA with the iScript cDNA Synthesis Kit (BioRad Laboratories Inc.) according to the manufacturer's instructions. Quantitative reverse-transcription PCR was performed in an iCycler Thermal Cycler with an iQ5 Multicolor Real-Time PCR Detection System (Bio-Rad Laboratories Inc.). Each reaction was prepared in a total volume of $20 \mu$ containing $1 \mu \mathrm{l}$ of cDNA, $250 \mathrm{nM}$ each primer, and $10 \mu \mathrm{l}$ of the iQ SYBR Green Supermix (Bio-Rad Laboratories Inc.). The primer pair Bos1F (5'-TCGAA CGCGTAGCAGCTCTC-3') and Bos1R (5'-ACCTTCTGTGCC GACCTCTC-3') was used for the analysis of bos 1 expression. The primer set was verified by standard curves for amplification efficiencies of 90 to $95 \%$ and for absence of nonspecific amplicons. The cycle conditions were as follows: $3 \mathrm{~min}$ at $95^{\circ} \mathrm{C}$ followed by 40 cycles of denaturation at $95^{\circ} \mathrm{C}$ for $30 \mathrm{~s}$, primer annealing at $56^{\circ} \mathrm{C}$ for $30 \mathrm{~s}$, and elongation at $72^{\circ} \mathrm{C}$ for $25 \mathrm{~s}$. This cycle was followed by a melting curve analysis, ranging from 55 to $95^{\circ} \mathrm{C}$, with temperature increasing in steps of $0.5^{\circ} \mathrm{C}$ every $30 \mathrm{~s}$.

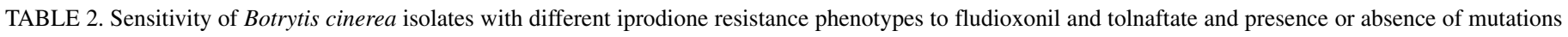
in the class III histidine-kinase Bos1

\begin{tabular}{|c|c|c|c|c|c|c|c|c|c|}
\hline \multirow[b]{2}{*}{ Type $^{\mathrm{v}}$} & \multirow[b]{2}{*}{ Isolate } & \multirow[b]{2}{*}{ Host } & \multicolumn{5}{|c|}{ Amino acid substitution in Bos 1} & \multicolumn{2}{|c|}{ Sensitivity $^{z}$} \\
\hline & & & $\mathrm{F} 127^{\mathrm{w}}$ & $\mathrm{I} 365^{\mathrm{x}}$ & Q369y & N373y & V1136 & Fludioxonil & Tolnaftate \\
\hline SS & MER2 & Strawberry & $\ldots$ & $\ldots$ & $\ldots$ & $\ldots$ & $\ldots$ & $\mathrm{S}$ & $\mathrm{S}$ \\
\hline \multirow[t]{3}{*}{$\mathrm{S}$} & CA25 & Blackberry & $\ldots$ & $\ldots$ & $\ldots$ & $\ldots$ & $\ldots$ & $\mathrm{S}$ & $\mathrm{S}$ \\
\hline & $\mathrm{CBa} 3$ & Blackberry & $\ldots$ & $\ldots$ & $\ldots$ & $\ldots$ & $\ldots$ & $\mathrm{S}$ & $\mathrm{S}$ \\
\hline & MV8 & Strawberry & $\ldots$ & $\ldots$ & $\ldots$ & $\ldots$ & $\ldots$ & $\mathrm{S}$ & $\mathrm{S}$ \\
\hline \multirow[t]{7}{*}{ LR } & MC14 & Blackberry & $\ldots$ & $S$ & $\ldots$ & $\ldots$ & $\ldots$ & $\mathrm{S}$ & $\mathrm{S}$ \\
\hline & $12-104$ & Strawberry & $\mathrm{S}$ & $\mathrm{N}$ & $\ldots$ & $\ldots$ & $\ldots$ & $\mathrm{S}$ & $\mathrm{S}$ \\
\hline & GIK21 & Strawberry & $\ldots$ & $\mathrm{S}$ & $\ldots$ & $\ldots$ & $\ldots$ & $\mathrm{S}$ & $\mathrm{S}$ \\
\hline & JEY1 & Strawberry & $\ldots$ & $\mathrm{S}$ & $\ldots$ & $\ldots$ & $\ldots$ & $\mathrm{S}$ & $\mathrm{S}$ \\
\hline & JEY23 & Strawberry & $\ldots$ & S & $\ldots$ & $\ldots$ & $\ldots$ & $\mathrm{S}$ & $\mathrm{S}$ \\
\hline & MOD8 & Strawberry & $\ldots$ & $\mathrm{S}$ & $\ldots$ & $\ldots$ & I & $\mathrm{S}$ & $\mathrm{S}$ \\
\hline & SBY11 & Strawberry & $\ldots$ & $\mathrm{S}$ & $\ldots$ & $\ldots$ & $\ldots$ & $\mathrm{S}$ & $\mathrm{S}$ \\
\hline \multirow[t]{5}{*}{ MR } & $12-402$ & Strawberry & $\ldots$ & $\ldots$ & $\mathrm{P}$ & $\mathrm{S}$ & $\ldots$ & $\mathrm{S}$ & $\mathrm{S}$ \\
\hline & JEY4 & Strawberry & $\ldots$ & $\ldots$ & $\mathrm{P}$ & $\mathrm{S}$ & $\ldots$ & $\mathrm{S}$ & $\mathrm{S}$ \\
\hline & JEY6 & Strawberry & $\ldots$ & $\ldots$ & $\mathrm{P}$ & $\mathrm{S}$ & $\ldots$ & $\mathrm{S}$ & $\mathrm{S}$ \\
\hline & SBY9 & Strawberry & $\ldots$ & $\ldots$ & $\mathrm{P}$ & $\mathrm{S}$ & $\ldots$ & $\mathrm{S}$ & $\mathrm{S}$ \\
\hline & SBY23 & Strawberry & $\ldots$ & $\ldots$ & $\mathrm{P}$ & $\mathrm{S}$ & $\ldots$ & $\mathrm{S}$ & N/A \\
\hline \multirow[t]{6}{*}{ HR } & $\mathrm{CBa} 82$ & Blackberry & $\ldots$ & $\mathrm{S}$ & $\ldots$ & $\ldots$ & $\mathrm{I}$ & LR & $\mathrm{R}$ \\
\hline & $\mathrm{COa} 3$ & Blackberry & $S$ & $\mathrm{~N}$ & $\ldots$ & $\ldots$ & $\ldots$ & S & $\mathrm{S}$ \\
\hline & $\mathrm{CO} 20$ & Blackberry & $\mathrm{S}$ & $\mathrm{N}$ & $\ldots$ & $\ldots$ & $\ldots$ & $\mathrm{S}$ & $\mathrm{S}$ \\
\hline & $\mathrm{KC} 25$ & Blackberry & $\ldots$ & $\mathrm{S}$ & $\ldots$ & $\ldots$ & $\mathrm{I}$ & MR & $\mathrm{R}$ \\
\hline & KC33 & Blackberry & $\ldots$ & $\mathrm{S}$ & $\ldots$ & $\ldots$ & I & MR & $\mathrm{R}$ \\
\hline & Wland1 & Strawberry & $\ldots$ & $\mathrm{S}$ & $\ldots$ & $\ldots$ & I & LR & $\mathrm{R}$ \\
\hline
\end{tabular}

\footnotetext{
${ }^{\mathrm{v}}$ Iprodione resistance phenotype; HR = highly resistant.

${ }^{\mathrm{w}}$ Mutation was identified in this study for the first time.

${ }^{x}$ Mutations were previously described $(6,29,34,37)$.

y Mutations previously described $(2,6,34,36)$.

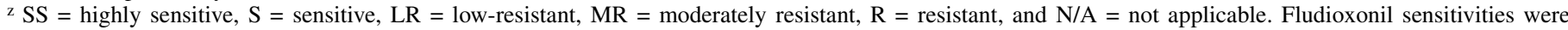
assessed according to Weber and Hahn (46) and tolnaftate sensitivities according to Kretschmer et al. (26). Sensitivity to fludioxonil was previously reported for isolate Wland1 (14) and all other isolates (15), except for 12-402 and 12-104.
} 
The expression of genes was calculated according to Pfaffl (38). Expression levels of bos 1 were normalized against the expression levels of the housekeeping gene actA with primer pair Act_RT_fw/ Act_RT_rev (27), and shown as normalized fold-expression relative to levels of noninduced germlings from the $\mathrm{S}$ isolate $\mathrm{CBa} 3$. Means and standard deviations were calculated from two biological replicates of each treatment. Three technical replicates of the PCR reaction were used for each biological replicate.

Evaluation of fitness components and in vivo sensitivity to fungicides. Isolates with various resistance phenotypes were assessed for their in vitro and in vivo fitness and in vivo fungicide sensitivity in comparison with wild-type isolates. Analyses of mycelial growth rate on PDA, in vitro spore production, in vivo pathogenicity, in vivo sensitivity to fungicides, and in vivo spore production were conducted exactly as previously described (15), with the exception that PDA was used instead of water agar; and Rovral 4 Flowable (41.6\% [wt/vol] active ingredient; Bayer CropScience) and Scholar SC (20.4\% [wt/vol] active ingredient; Syngenta Crop Protection, Greensboro, NC) formulated products were used at $2.5 \mathrm{ml} /$ liter for the assessment of in vivo pathogenicity and sensitivity to fludioxonil and iprodione in detached fruit assays. In order to reduce the potential influence of multiple fungicide resistance in the fitness study, we chose iprodione SS and $\mathrm{S}$ isolates that were either $\mathrm{S}$ to all seven classes of fungicides (isolate GIK2) or isolates that only differed in their resistance to iprodione but otherwise had the same resistance profiles. Specifically, MR isolates JEY6 and SBY9 were R to APs, MBCs, SDHIs, and QoIs, just like SS and S isolates JEY2, JEY8, and SBY24. SS isolate JEY21 resembled, in its phenotypic resistance profile, iprodione LR isolate GIK3 (both were R to MBCs, SDHIs, and QoIs); and S isolate GIK10 resembled, in its resistance profile, iprodione LR isolates JEY24 and SBY26 (all were $\mathrm{R}$ to APs, HAs, MBCs, SDHIs, and QoIs).

Data analysis. A statistical model related the experimental responses of the fitness test to replication, isolate, fungicide treatment, and their combination. The method of least squares was used to estimate the model terms connected with the factors. The data of the two independent experiments for each experimental response were combined and significant differences were determined through Tukey's honestly significant difference test. All calculations were performed by IBM SPSS Statistics (version 19; IBM SPSS, Armonk, NY) and all tests were performed with $\alpha=$ 0.05 , except as described otherwise.

\section{RESULTS}

Sensitivity of $\boldsymbol{B}$. cinerea isolates to iprodione. Most of the 245 field isolates from strawberry fruit were either SS (38\%) or S $(41 \%)$ to iprodione. Five isolates or 2\% (isolates 12-402 from Florida, SBY9 and SBY23 from North Carolina, and JEY4 and JEY6 from South Carolina) were MR, and 44 or $18 \%$ were LR to iprodione (Table 1). The isolate Wland1 from Virginia was HR to iprodione. Most isolates LR or MR to iprodione were observed in North Carolina (18\%) and South Carolina (23\%). A majority of isolates (27 of 30) from Florida were either SS of S whereas only $3 \%$ of the isolates were LR or MR to iprodione. Isolates LR to iprodione were found in two of four locations in North Carolina and in all seven locations in South Carolina, indicating that this phenotype was widespread but not present in every location in the Carolinas. Most LR and MR isolates were obtained from locations MOD, JEY, and SBY, which clustered in the western part of the Carolinas.

Amino acid variations in Bos1 of isolates with varying levels of resistance to iprodione. The bos 1 gene from one SS, one S, six $\mathrm{LR}$, five $\mathrm{MR}$, and one $\mathrm{HR}$ isolate were sequenced in its entirety, because amino acid changes in the Bos1 protein had previously been associated with resistance to iprodione. Two $S$, one LR, and five HR B. cinerea isolates from blackberry fruit were included in this sequence analysis. A combination of two point mutations in bos 1 was present in all MR isolates, resulting in the replacements of glutamine with proline at amino acid position 369 (Q369P; CAG to CCG) and asparagine with serine at amino acid position 373 (N373S; AAC to AGC) (Table 2). All LR and HR isolates had a mutation at codon 365 (ATC to AGC or AAC), resulting in amino acid change from isoleucine to either serine (I365S) or asparagine (I365N). Isolates containing the I365N mutation had an additional mutation at codon 127 (TTT to TCT), causing a substitution of phenylalanine to serine (F127S). Four of six HR isolates and one LR isolate with the I365S mutation (MOD8, CBa82, KC25, KC33, and Wland1) contained an additional change from valine to isoleucine at amino acid position 1136 (V1136I; GTC to ATC). A fragment of bos 1 was sequenced from nine additional LR isolates (10-43, JEY2, JEY25, KUD19, MOD4, SBY1, SBY4, SBY7, and SBY10) to investigate whether the mutation I365S/N was characteristic for isolates LR to iprodione. The same isolates were also screened for the F127S and V1136I mutations by allele-specific PCR and restriction length polymorphism, respectively (data not shown). The combination of F127S and I365N mutations, which had been found in isolates 12-104, COa3, and CO20 (Table 2), was also present in LR isolates 10-43, SBY1, and SBY10. The combination of I365S and V1136I mutations, which had been found in isolates MOD8, CBa82, KC25, KC33, and Wland1 (Table 2), was also present in LR isolates JEY2, JEY25, KUD19, MOD4, SBY4, and SBY7. No single amino acid change or any amino acid change combination in Bos1 was associated with the HR phenotype, indicating that mutations in bos 1 were not responsible for the HR phenotype.

Some isolates contained uncommon nucleotide changes leading to amino acid variations. The D757L mutation was present in one (isolate MC14) and the P972L mutation in three LR isolates (GIK21, JEY1, and JEY23). The same isolates also contained the I365S mutation associated with LR resistance; thus, it is unclear whether D757L and P972L contribute to the LR phenotype. Two amino acid variations at position 1259 (substitution of threonine by proline or alanine) were found in $\mathrm{R}$ and $\mathrm{S}$ isolates and, thus, did not correlate with resistance. Interestingly, two isolates (MOD8 and 12-104) categorized as $\mathrm{S}$ to iprodione did contain the amino acid substitution I365S/N characteristic for LR, confirming our observations that the distinction between $\mathrm{S}$ and LR isolates was not always easy to make in our sensitivity assay.

Analysis of bos 1 expression levels. Because point mutations in target gene bos 1 could not explain the HR phenotype, we investigated its expression in germlings with and without iprodione ex-

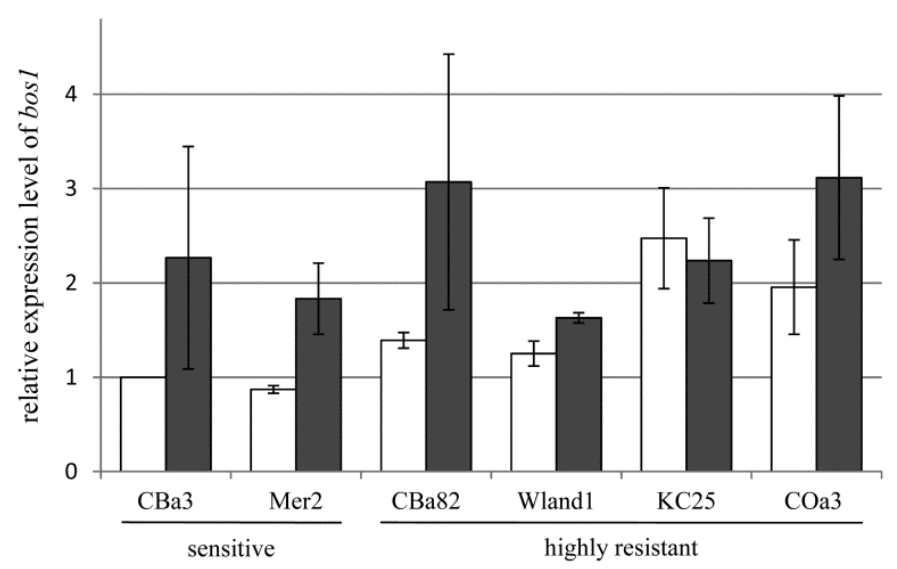

Fig. 1. Analysis of bos 1 expression in germlings with and without exposure to iprodione prior to RNA extraction. Values were normalized with housekeeping gene $(\beta)$-actin and indicate fold-expression relative to the expression levels of sensitive isolate $\mathrm{CBa} 3$. White bars indicate expression without iprodione exposure and gray bars with iprodione exposure. Mean values and standard deviations were calculated from two biological replicates. 
posure prior to RNA extraction. Constitutive expression of bos 1 was consistently lowest in the two $\mathrm{S}$ isolates and HR isolates $\mathrm{CBa} 82$ and Wland1 but twice as high in HR isolates $\mathrm{KC} 25$ and $\mathrm{COa} 3$. With the exception of isolate $\mathrm{KC} 25$, iprodione exposure slightly but significantly induced bos 1 expression levels in $\mathrm{S}$ and HR isolates (Fig. 1).

Sensitivity of $B$. cinerea isolates to fludioxonil and tolnaftate. Cross resistance between DCs and PPs is a well-known phenomenon in laboratory mutants. We found that our iprodione SS, S, LR, and MR field isolates were S to fludioxonil (Table 2). The six iprodione HR isolates had three different phenotypes with respect to their sensitivity to fludioxonil. Two were S (COa3 and CO20), two were LR (CBa82 and Wland1), and two were MR (KC25 and KC33) to fludioxonil. None of the amino acid changes found in Bos1 or any amino acid combination was distinctly associated with resistance to fludioxonil, including the fludioxonil LR and MR phenotypes. The four isolates $\mathrm{R}$ to fludioxonil were also the only ones $\mathrm{R}$ to tolnaftate, an indication that multidrug resistance activity based on drug efflux pumps may be involved.

Evaluation of fitness components and in vivo sensitivity to fungicides. Isolates with various resistance phenotypes to iprodione were assessed for their in vitro and in vivo fitness and in vivo fungicide sensitivity. Iprodione $L R, M R$, and $H R$ isolates grew as fast on PDA and produced as many spores in vitro as the $\mathrm{S}$ and SS isolates (Table 3). Although some isolates developed significantly different lesion sizes on nontreated strawberry fruit, no correlation was observed between lesion size and resistance phenotype. Field rates of Rovral 4 Flowable controlled the S isolates but not the LR or MR isolates or the HR isolate included in this study. There were no significant differences in lesion size and sporulating lesions among and between MR and LR isolates; however, LR isolates had significantly smaller lesion sizes and sporulated less on strawberry fruit treated with Rovral 4 Flowable compared with the HR isolates. Only the fludioxonil LR isolate (Wland1) produced a sporulating lesion on fruit treated with Scholar SC fungicide (Table 3).

\section{DISCUSSION}

This study documents that resistance to iprodione in B. cinerea from strawberry fields in North and South Carolina is widely distributed but low in prevalence. Isolates $\mathrm{R}$ to iprodione were found in the majority ( 9 of 11) of strawberry fields examined. The frequency of LR and MR isolates obtained from fields in Florida,
North Carolina, and South Carolina was low (3, 18, and 23\%, respectively) compared with the frequencies reported in previous studies. The overall frequency of $B$. cinerea isolates R to DCs from strawberry fields in Australia, Louisiana, New Zealand, Oregon, and Spain was 45, 55, 25, 41, and 44\%, respectively $(3,11,12,44,45,47,48)$. The relatively low frequency of resistance observed in our study may be due to limited exposure of $B$. cinerea isolates in strawberry fields to DCs in recent years. In the United States, use of DCs was restricted to one application per season prior to bloom after 1998, due to human exposure concerns (40). This not only dramatically reduced the number of permitted sprays per season in the United States for strawberry, it also prevented farmers from using this product during the peak time of infection. This change in use pattern could also explain why fewer HR isolates were collected from strawberry fields ( 1 of 215 isolates) compared with blackberry fields (5 of 202 isolates), where four iprodione applications are still permitted up to harvest.

Mutations in bosl were present in all of the $\mathrm{R} B$. cinerea isolates but amino acid changes could only be associated distinctly with the LR and MR phenotypes. The I365S/N/R mutations were associated with low levels of resistance to DCs in $B$. cinerea isolates from England, France, Israel, Italy, Japan, New Zealand, Switzerland, and the United States $(6,9,29,34,37)$. Consistent with these published studies, mutations I365S and I365N were associated with the LR phenotype in our collection. The MR phenotype was associated with a combination of amino acid changes Q369P and N373S in our study, which was consistent with other reports $(2,6,34,36)$. However, none of the mutations or mutation combinations in bos 1 was uniquely associated with the HR phenotype. In previous studies, HR laboratory mutants contained point mutations in bos 1 resulting in various amino acid alterations including G278, G232C, G357N, G415D, G446S, G493T, and P742T) $(8,9,20)$. The presence of mutations in bos1 associated with LR in our HR field mutants indicates that additional mechanisms of resistance to iprodione may be involved. Multidrug resistance based on overexpression of gene $m f s M 2$ encoding a major facilitator transporter has been shown to confer low levels of resistance to iprodione (26). We investigated the expression of $m f s M 2$ in both iprodione $\mathrm{S}$ and HR isolates but no significant differences in expression were found (data not shown). Interestingly, four of the six HR isolates that carried the mutations I365S or I365N associated with LR and were also R to fludioxonil and tolnaftate, which could be an indication for a different multidrug efflux pump activity (26). The other two iprodione HR

TABLE 3. Fitness components for Botrytis cinerea isolates with different sensitivity to iprodione ${ }^{y}$

\begin{tabular}{|c|c|c|c|c|c|c|c|c|c|c|}
\hline \multirow[b]{4}{*}{ Isolates } & & & \multicolumn{4}{|c|}{ Fitness components } & \multicolumn{4}{|c|}{ In vivo fungicide sensitivity assay } \\
\hline & & & In vitro e & periments & In vivo & riments & Rovral & Scholar & Rovral & Scholar \\
\hline & \multicolumn{2}{|c|}{ Phenotype ${ }^{z}$} & $\begin{array}{l}\text { Mycelial growth } \\
\text { (Ø in cm) }\end{array}$ & Spores $\times 10^{4} / \mathrm{ml}$ & $\begin{array}{c}\text { Lesion size } \\
(\varnothing \text { in } \mathrm{cm})\end{array}$ & $\begin{array}{l}\text { Sporulating } \\
\text { lesions }(\%)\end{array}$ & \multicolumn{2}{|c|}{$\begin{array}{l}\text { Lesion size } \\
(\varnothing \text { in } \mathrm{cm})\end{array}$} & \multicolumn{2}{|c|}{$\begin{array}{l}\text { Sporulating } \\
\text { lesions (\%) }\end{array}$} \\
\hline & Ipr & Flu & 3 dai & 10 dai & 4 dai & 4 dai & 4 dai & 4 dai & 4 dai & 4 dai \\
\hline GIK2 & SS & $\mathrm{S}$ & $7.6 \mathrm{c}$ & $9.2 \mathrm{a}$ & $2.5 \mathrm{cde}$ & 100.0 & $0.0 \mathrm{a}$ & 0.0 & $0.0 \mathrm{a}$ & 0.0 \\
\hline JEY8 & SS & $\mathrm{S}$ & $7.1 \mathrm{ab}$ & $116.5 \mathrm{bc}$ & 2.4 bcde & 100.0 & $0.1 \mathrm{a}$ & 0.0 & $0.0 \mathrm{a}$ & 0.0 \\
\hline GIK10 & $\mathrm{S}$ & $\mathrm{S}$ & $7.4 \mathrm{bc}$ & $88.7 \mathrm{~b}$ & $2.1 \mathrm{abc}$ & 100.0 & $0.0 \mathrm{a}$ & 0.0 & $0.0 \mathrm{a}$ & 0.0 \\
\hline SBY24 & $\mathrm{S}$ & $\mathrm{S}$ & $7.0 \mathrm{a}$ & $19.2 \mathrm{a}$ & $2.3 \mathrm{bcd}$ & 100.0 & $0.0 \mathrm{a}$ & 0.0 & $0.0 \mathrm{a}$ & 0.0 \\
\hline GIK3 & LR & $\mathrm{S}$ & $7.4 \mathrm{bc}$ & $120.8 \mathrm{bc}$ & $2.0 \mathrm{ab}$ & 100.0 & $0.8 \mathrm{~b}$ & 0.0 & $60.7 \mathrm{~b}$ & 0.0 \\
\hline JEY24 & LR & $\mathrm{S}$ & $7.0 \mathrm{a}$ & $17.5 \mathrm{a}$ & $1.7 \mathrm{a}$ & 100.0 & $0.5 \mathrm{ab}$ & 0.0 & $21.6 \mathrm{a}$ & 0.0 \\
\hline SBY26 & LR & $\mathrm{S}$ & $7.5 \mathrm{c}$ & $14.2 \mathrm{a}$ & $2.6 \mathrm{de}$ & 100.0 & $1.0 \mathrm{bc}$ & 0.0 & $58.5 \mathrm{~b}$ & 0.0 \\
\hline JEY6 & MR & $\mathrm{S}$ & $7.5 \mathrm{c}$ & $204.2 \mathrm{e}$ & 2.4 bcde & 100.0 & $2.3 \mathrm{~d}$ & 0.0 & $100.0 \mathrm{c}$ & 0.0 \\
\hline SBY9 & MR & $\mathrm{S}$ & $7.4 \mathrm{bc}$ & $137.5 \mathrm{~cd}$ & $3.1 \mathrm{f}$ & 100.0 & $1.7 \mathrm{~cd}$ & 0.0 & $100.0 \mathrm{c}$ & 0.0 \\
\hline
\end{tabular}

y Numbers in each column followed by the same letter are not significantly different at $\alpha=0.05$ as determined by analysis of variance. Mean separation was conducted using Tukey's HSD test; dai = days after inoculation.

${ }^{\mathrm{z}}$ Differentiation between isolates that are sensitive (S) and low resistant (LR) to fludioxonil (Flu) was based on a spore germination assay using fludioxonil at 0.1 and $10 \mathrm{mg} /$ liter; differentiation between iprodione (Ipr) highly sensitive (SS), S, LR, moderately resistant (MR), and highly resistant (HR) isolates was based on the same assay with iprodione at 5 and $50 \mathrm{mg} / \mathrm{liter}$ (46). 
isolates carried the mutations F127S and $1365 \mathrm{~N}$ associated with LR but were $S$ to tolnaftate and fludioxonil. That suggests that, in addition to mutations in bos 1 and drug efflux pump activity, a third mechanism of resistance may be involved in the development of HR phenotypes in $B$. cinerea field isolates. The expression level of bos 1 was analyzed in this study as a possible third mechanism of resistance. Though two isolates showed a 2- to 2.5-fold overexpression of bos 1 in the absence of iprodione, this evidence is insufficient to conclude that overexpression of bos 1 results in resistance to iprodione.

Isolates displaying iprodione resistance in vitro also caused gray mold disease on detached fruit treated with the recommended label rate of Rovral 4 Flowable, which demonstrates the significance of isolates with different resistance phenotypes for commercial strawberry production. Isolates with LR, MR, and HR phenotypes were pathogenic on strawberry fruit treated with Rovral 4 Flowable. MR and HR isolates were equally aggressive but LR isolates had smaller lesion sizes and sporulated less compared with the HR isolate. Considering the relatively harsh inoculation method we used to induce infection (stab inoculation to simulate insect damage and injection of spores), especially LR but possibly also MR and HR isolates may still be controlled in the field with DC fungicides. Further studies are needed to investigate whether LR, MR, and HR isolates are able to cause disease under field conditions when insects are sufficiently controlled. Previous fitness studies found that DC-R B. cinerea field isolates did not differ from $\mathrm{S}$ isolates in regard to radial growth rate on artificial medium, sporulation, and pathogenicity, which is in line with our findings $(3,6,36)$; however, one study reports that sclerotia of DC R isolates survived less compared with $\mathrm{S}$ isolates (39). A previous study also showed reduced in vitro growth rate, sporulation rate, and lesion development in laboratory mutants with the HR phenotype (20). However, we established that the molecular basis of resistance in our isolates is different (not based solely on target gene mutations) and that our HR isolate did not suffer a competitive disadvantage compared with $\mathrm{S}$ isolates in our fitness study. Therefore, resistance management programs should not rely on the exploitation of reduced fitness as a tool to control MR and HR mutants.

Cross resistance between DCs and PPs is a common phenomenon in fungal pathogens, because both classes of fungicides interfere with the osmoregulatory pathway. For example, field isolates of Alternaria brassicicola and laboratory mutants of Aspergillus parasiticus had previously shown high levels of cross resistance between those two fungicides $(23,35)$. In $B$. cinerea, cross resistance between DCs and PPs is frequently observed in laboratory strains but rarely found under field conditions $(13,20$, $22,28,53)$, which is in line with our findings. The majority of our isolates (two isolates $\mathrm{HR}$ and all isolates MR and LR to iprodione) were $\mathrm{S}$ to the PP fludioxonil; only four of the six isolates $\mathrm{HR}$ to iprodione were also $\mathrm{R}$ to fludioxonil. In laboratory mutants, cross resistance between DCs and PPs was associated with mutations in bos 1 but analysis of crosses between field isolates $\mathrm{R}$ to DCs and PPs suggested that different genes regulate resistance to these two fungicides $(13,20,42)$. No mutation in bosl was associated with resistance to fludioxonil in our field isolates. Further studies are needed to investigate mechanisms of fludioxonil resistance, including multidrug resistance activity, which has previously been shown to confer resistance to fludioxonil and, in some cases, also to iprodione (26).

In conclusion, iprodione resistance is widespread but only accounts for a relatively small percentage of the $B$. cinerea population of the southeastern United States. Interestingly, only LR and MR phenotypes were associated with target gene mutations, indicating that the HR phenotype in field strains is caused by different, still-unknown mechanisms. Although the commercial significance of the LR phenotype has not yet been established, MR and HR phenotypes were not controlled on detached fruit sprayed with label rates of Rovral and resistance should be monitored in commercial strawberry fields.

\section{ACKNOWLEDGMENTS}

Technical contribution number 6056 of the Clemson University Experiment Station. This work was supported by the CSREES United States Department of Agriculture (USDA) under project number SC-1000642 and the USDA SCRI Grants Program number 2010-51181-21113. D. Fernández-Ortuño has received funding from the Marie Curie COFUND program "U-Mobility" co-financed by Universidad de Málaga and the European Community's Seventh Framework Program under Grant Agreement Number 246550.

\section{LITERATURE CITED}

1. Amiri, A., Heath, S. M., and Peres, N. A. 2013. Phenotypic characterization of multifungicide resistance in Botrytis cinerea isolates from strawberry fields in Florida. Plant Dis. 97:393-401.

2. Banno, S., Fukumori, F., Ichiishi, A., Okada, K., Uekusa, H., Kimura, M., and Fujimura, M. 2008. Genotyping of benzimidazole-resistant and dicarboximide-resistant mutations in Botrytis cinerea using real-time polymerase chain reaction assays. Phytopathology 98:397-404.

3. Beever, R. E., and Brien, H. M. R. 1983. A survey of resistance to the dicarboximide fungicides in Botrytis cinerea. N.Z. J. Agric. Res. 26:391-400.

4. Butler Carver, L. M., Louws, F. J., and Fernandez, G. E. 1998. In vitro resistance of Botrytis cinerea from strawberry to the fungicides benomyl, iprodione, and vinclozolin. (Abstr.) Phytopathology 88:S13.

5. Chi, M. H., Park, S. Y., and Lee, Y. H. 2009. A quick and safe method for fungal DNA extraction. Plant Pathol. J. 25:108-111.

6. Cui, W., Beever, R. E., Parkes, S. L., and Templeton, M. D. 2004. Evolution of an osmosensing histidine kinase in field strains of Botryotinia fuckeliana (Botrytis cinerea) in response to dicarboximide fungicide usage. Phytopathology 94:1129-1135.

7. Cui, W., Beever, R. E., Parkes, S. L., Weeds, P. L., and Templeton, M. D. 2002. An osmosensing histidine kinase mediates dicarboximide fungicide resistance in Botryotinia fuckeliana (Botrytis cinerea). Fungal Genet. Biol. 36:187-198.

8. De Miccolis Angelini, R. M., Pallastro, S., and Faretra, F. 2012. Genetics of fungicide resistance in Botryotinia fuckeliana (Botrytis cinerea). Pages 237-250 in: Fungicide Resistance in Crop Protection: Risk and Management. T. S. Thind, ed. CABI, Oxfordshire, UK and Cambridge, MA.

9. De Miccolis Angelini, R. M., Rotolo, C., Habib, W., Pallastro, S., and Faretra, F. 2007. Single nucleotide polymorphisms (SNPs) in Botryotinia fuckeliana genes involved in fungicide resistance. Pages 64 in: Abstr. Book 14th Int. Botrytis Symp. African Sun Media Pty., Cape Town, South Africa.

10. Detweiler, A. R., Vargas, J. M., Jr., and Danneberger, T. K. 1983. Resistance of Sclerotinia homoeocarpa to iprodione and benomyl. Plant Dis. 67:627-630.

11. Dianez, F., Santos, M., Blanco, R., and Tello, J. C. 2002. Fungicide resistance in Botrytis cinerea isolates from strawberry crops in Huelva (southwestern Spain). Phytoparasitica 30:529-534.

12. Elad, Y., Yunis, H., and Katan, T. 1992. Multiple fungicide resistance to benzimidazoles, dicarboximides and diethofencarb in field isolates of Botrytis cinerea in Israel. Plant Pathol. 41:41-46.

13. Faretra, F., and Pollastro, S. 1993. Isolation, characterization and genetic analysis of laboratory mutants of Botryotinia fuckeliana resistant to the phenylpyrrole fungicide CGA 173506. Mycol. Res. 97:620-624.

14. Fernández-Ortuño, D., Bryson, P. K., Grabke, A., and Schnabel, G. 2013. First report of fludioxonil resistance in Botrytis cinerea from a strawberry field in Virginia. Plant Dis. 97:848. Online publication. http://dx.doi.org/ 10.1094/PDIS-01-13-0012-PDN

15. Fernández-Ortuño, D., Chen, F., and Schnabel, G. 2013. Resistance to cyprodinil and lack of fludioxonil resistance in Botrytis cinerea isolates from strawberry in North and South Carolina. Plant Dis. 97:81-85.

16. Fernández-Ortuño, D., Chen, F., and Schnabel, G. 2012. Resistance to pyraclostrobin and boscalid in Botrytis cinerea isolates from strawberry fields in the Carolinas. Plant Dis. 96:1198-1203.

17. Fernández-Ortuño, D., Li, X., Wang, F., and Schnabel, G. 2011. First report of gray mold of strawberry caused by Botrytis cinerea in South Carolina. Plant Dis. 95:1482.

18. Fernández-Ortuño, D., Li, X., Wang, F., and Schnabel, G. 2012. First report of gray mold of strawberry caused by Botrytis caroliniana in North Carolina. Plant Dis. 96:914.

19. Fernández-Ortuño, D., and Schnabel, G. 2012. First report of thiophanatemethyl resistance in Botrytis cinerea on strawberry from South Carolina. Plant Dis. 96:1700. 
20. Fillinger, S., Ajouz, S., Nicot, P. C., Leroux, P., and Bardin, M. 2012. Functional and structural comparison of pyrrolnitrin- and iprodioneinduced modifications in the class III histidine-kinase Bos1 of Botrytis cinerea. PLoS One 7:e42520.

21. Grabke, A., Fernández-Ortuño, D., and Schnabel, G. 2013. Fenhexamid resistance in Botrytis cinerea from strawberry fields in the Carolinas is associated with four target gene mutations. Plant Dis. 97:271-276.

22. Hilber, U. W., Schwinn, F. J., and Schüepp, H. 1995. Comparative resistance patterns of fludioxonil and vinclozolin in Botryotinia fuckeliana. J. Phytopathol. 143:423-428.

23. Iacomi-Vasilescu, B., Avenot, H., Bataillé-Simoneau, N., Laurent, E., Guénard, M., and Simoneau, P. 2004. In vitro fungicide sensitivity of Alternaria species pathogenic to crucifers and identification of Alternaria brassicicola field isolates highly resistant to both dicarboximides and phenylpyrroles. Crop Prot. 23:481-488.

24. Johnson, K. B., Sawyer, T. L., and Powelson, M. L. 1994. Frequency of benzimidazole- and dicarboximide-resistant strains of Botrytis cinerea in western Oregon small fruit and snap bean plantings. Plant Dis. 78:572-577.

25. Katan, T. 1982. Resistance to 3,5-dichlorophenyl-N-cyclic imide ('dicarboximide') fungicides in the grey mould pathogen Botrytis cinerea on protected crops. Plant Pathol. 31:133-141.

26. Kretschmer, M., Leroch, M., Mosbach, A., Walker, A.-S., Fillinger, S., Mernke, D., Schoonbeek, H., Pradier, J.-M., Leroux, P., and De Waard, M. A. 2009. Fungicide-driven evolution and molecular basis of multidrug resistance in field populations of the grey mould fungus Botrytis cinerea. PLoS Pathog. 5:e1000696.

27. Leroch, M., Mernke, D., Koppenhoefer, D., Schneider, P., Mosbach, A., Doehlemann, G., and Hahn, M. 2011. Living colors in the gray mold pathogen Botrytis cinerea: Codon-optimized genes encoding green fluorescent protein and mCherry, which exhibit bright fluorescence. Appl. Environ. Microbiol. 77:2887.

28. Leroux, P., Chapeland, F., Desbrosses, D., and Gredt, M. 1999. Patterns of cross-resistance to fungicides in Botryotinia fuckeliana (Botrytis cinerea) isolates from French vineyards. Crop Prot. 18:687-697.

29. Leroux, P., Fritz, R., Debieu, D., Albertini, C., Lanen, C., Bach, J., Gredt, M., and Chapeland, F. 2002. Mechanisms of resistance to fungicides in field strains of Botrytis cinerea. Pest Manage. Sci. 58:876-888.

30. Li, X., Fernández-Ortuño, D., Chai, W., Wang, F., and Schnabel, G. 2012. Identification and prevalence of Botrytis spp. from blackberry and strawberry fields of the Carolinas. Plant Dis. 96:1634-1637.

31. Li, X., Kerrigan, J., Chai, W., and Schnabel, G. 2012. Botrytis caroliniana, a new species isolated from blackberry in South Carolina. Mycologia 104:650-658.

32. Liu, W., Leroux, P., and Fillinger, S. 2008. The HOG1-like MAP kinase Sak1 of Botrytis cinerea is negatively regulated by the upstream histidine kinase Bos1 and is not involved in dicarboximide- and phenylpyrroleresistance. Fungal Genet. Biol. 45:1062-1074

33. Locke, T., and Fletcher, J. T. 1988. Incidence of benomyl and iprodione resistance in isolates of Botrytis cinerea in tomato crops in England and Wales in 1986. Plant Pathol. 37:381-384.

34. Ma, Z., Yan, L., Luo, Y., and Michailides, T. J. 2007. Sequence variation in the two-component histidine kinase gene of Botrytis cinerea associated with resistance to dicarboximide fungicides. Pestic. Biochem. Physiol. 88:300-306.

35. Markoglou, A. N., Doukas, E. G., and Ziogas, B. N. 2008. Phenylpyrroleresistance and aflatoxin production in Aspergillus parasiticus Speare. Int. J. Food Microbiol. 127:268-275.

36. Oshima, M., Banno, S., Okada, K., Takeuchi, T., Kimura, M., Ichiishi, A.,
Yamaguchi, I., and Fujimura, M. 2006. Survey of mutations of a histidine kinase gene BcOS1 in dicarboximide-resistant field isolates of Botrytis cinerea. J. Gen. Plant Pathol. 72:65-73.

37. Oshima, M., Fujimura, M., Banno, S., Hashimoto, C., Motoyama, T., Ichiishi, A., and Yamaguchi, I. 2002. A point mutation in the twocomponent histidine kinase $B c O S-1$ gene confers dicarboximide resistance in field isolates of Botrytis cinerea. Phytopathology 92:75-80.

38. Pfaffl, M. W. 2001. A new mathematical model for relative quantification in real-time RT-PCR. Nucleic Acids Res. 29:e45.

39. Raposo, R., Gomez, V., Urrutia, T., and Melgarejo, P. 2000. Fitness of Botrytis cinerea associated with dicarboximide resistance. Phytopathology 90:1246-1249.

40. United States Environmental Protection Agency. 1998. Prevention, Pesticides, and Toxic Substances. R.E.D. facts: iprodione. U.S. EPA, Washington, DC.

41. Viaud, M., Fillinger, S., Lui, W., Polepalli, J. S., Le Pêcheur, P., Kunduru, A. R., Leroux, P., and Legendre, L. 2006. A class III histidine kinase acts as a novel virulence factor in Botrytis cinerea. Mol. Plant-Microbe Interact. 19:1042-1050.

42. Vignutelli, A., Hilber-Bodmer, M., and Hilber, U. W. 2002. Genetic analysis of resistance to the phenylpyrrole fludioxonil and the dicarboximide vinclozolin in Botryotinia fuckeliana (Botrytis cinerea). Mycol. Res. 106:329-335.

43. Wang, Z. N., Cooley-Smith, J. R., and Wareing, W. 1986. Dicarboximide resistance in Botrytis cinerea in protected lettuce. Plant Pathol. 35:427433.

44. Washington, W. S., Shanmuganathan, N., and Forbes, C. 1992. Fungicide control of strawberry fruit rots, and the field occurrence of resistance of Botrytis cinerea to iprodione, benomyl and dichlofluanid. Crop Prot. 11:355-360.

45. Weber, R. W. S. 2011. Resistance of Botrytis cinerea to multiple fungicides in Northern German small-fruit production. Plant Dis. 95:1263-1269.

46. Weber, R. W. S., and Hahn, M. 2011. A rapid and simple method for determining fungicide resistance in Botrytis. J. Plant Dis. Prot. 118:17-25.

47. Wedge, D. E., Curry, K. J., Boudreaux, J. E., Pace, P. F., and Smith, B. J. 2001. A microtiter assay demonstrates sensitivity and resistance profiles for Botrytis cinerea isolates from Louisiana strawberry farms. Adv. Strawberry Res. 20:27-33.

48. Wedge, D. E., Pace, P. F., Boudreaux, J. E., Curry, K. J., and Smith, B. J. 2002. Fungicide sensitivity and resistance profiles for Botrytis cinerea isolates from Louisiana strawberry farms. (Abstr.) Phytopathology 92:S153.

49. Williamson, B., Tudzynski, B., Tudzynski, P., and van Kan, J. J. A. L. 2007. Botrytis cinerea: The cause of grey mould disease. Mol. Plant Pathol. 8:561-580.

50. Yoshimura, M. A., Luo, Y., Ma, Z., and Michailides, T. J. 2004. Sensitivity of Monilinia fructicola from stone fruit to thiophanate-methyl, iprodione, and tebuconazole. Plant Dis. 88:373-378

51. Yourman, L. F., and Jeffers, S. N. 1999. Resistance to benzimidazole and dicarboximide fungicides in greenhouse isolates of Botrytis cinerea. Plant Dis. 83:569-575.

52. Zhu, F., Bryson, P. K., and Schnabel, G. 2012. Influence of storage approaches on instability of propiconazole resistance in Monilinia fructicola. Pest Manage. Sci. 68:1003-1009.

53. Ziogas, B. N., and Kalamarakis, A. E. 2001. Phenylpyrrole fungicides: Mitotic instability in Aspergillus nidulans and resistance in Botrytis cinerea. J. Phytopathol. 149:301-308. 